\title{
Atrocities and confrontational tension
}

\author{
Stefan Klusemann* \\ Department of Sociology, University of Pennsylvania, Philadelphia, PA, USA
}

Edited by:

Guillaume Poirier, Ecole Polytechnique

Fédérale de Lausanne, Switzerland

Reviewed by:

Susanne Karstedt,

University of Leeds, UK

Jack Katz, University of California at

Los Angeles, USA

*Correspondence:

Stefan Klusemann, Department of

Sociology, University of Pennsylvania,

3718 Locust Walk, Philadelphia,

PA 19104-6299, USA.

e-mail: stefankl@ssc.upenn.edu
This paper presents an analysis of video-recordings and other micro-level data of the 1995 Srebrenica massacre in Bosnia-and-Herzegovina. It focuses on the sequential unfolding of micro-interactions and emotional dynamics before, and over the course of the atrocity. The paper argues that massacres have a pattern of situational emergence: local emotional dynamics are crucial to explain where and when atrocities do or do not come off and what form they take on the micro-level. It is shown that (1) micro-interactions constitute situational turning-points, towards or away from atrocities and that (2) local emotional dynamics shape the internal structure of atrocities, i.e. their internal dynamics of killings. The analysis is based on recent advances in the micro-sociology of violence by Collins, Katz, and Grossman, as well as Ekman's research tools for identifying emotional cues in micro-data.

Keywords: violence, atrocities, emotions, micro-interactions, confrontational tension, Srebrenica

\section{INTRODUCTION - ATROCITIES AND THE MICRO-SOCIOLOGY OF VIOLENCE}

Recent advances in the micro-sociology of violence (Katz, 1988; Grossman, 1996, 2004; Klinger, 2004; Collins, 2008) show that situational, emotional dynamics of micro-interactions largely "determine what kinds of violence will or will not happen, and when and how" (Collins, 2008:20). What gets done in terms of violence is patterned by local, emotional dynamics. Following these findings, this paper presents a critique of prevalent approaches in the study of war and civil war atrocities ${ }^{1}$. The latter have been focusing on background factors, far away from the immediate micro-situations in which atrocities actually occur: e.g. ethnic conflict, collective frames that de-legitimize an opponent, or vengeance of perceived humiliations. In contrast, this paper shows that micro-situational dynamics are crucial to explain where and when atrocities do or do not come off and what they look like on the micro-level. It does so by means of a close look at a particular case, the 1995 Srebrenica massacre in Bosnia-and-Herzegovina in which more than 7000 Bosnian Muslim men were killed after the Bosnian Serb Army had overrun the UN enclave of Srebrenica. The atrocity is of particular interest since the rich micro-data available (incl. video-material) gets us close into the dynamics of the situation.

\section{MICRO-SITUATIONAL DYNAMICS AND ATROCITIES}

The micro-sociology of violence suggests that for an explanation of atrocities we need to put "the interaction in the centre of analysis, not $[\ldots]$ (the) background $[\ldots]$ or even the motivation" (Collins, 2008: 1). Standard explanations of atrocities that emphasize background-variables and motives such as ethnic hatred, vengeance, or collective frames of racial/ethnic superiority, fall short of a sufficient argument in two respects: (1) They are insufficient to explain where and when atrocities do or do not come off; these approaches sample

${ }^{1}$ With the term war and civil-war atrocities I refer to incidents of multiple close-up killings of civilians and/or disarmed soldiers; often these incidents involve rapes. on the dependent variable. Where ethnic prejudices or longings of vengeance exist, they are typically more common than atrocities ${ }^{2}$. Hence there must be specific conditions under which prejudiced persons commit atrocities. As we will see in the Srebrenica case, situational factors can prevent motivated people from acting on their prejudices or it can pull people into murderous activity that they may not have been planning.

With regard to Serbian violence against Bosnian Muslims, studies have often cited the Balkan's history of ethnic rivalry. Volkan (2004) argues for example that Serbian violence can be explained by the lasting emotional impact of the Serbian defeat at the Battle of Kosovo in 1389 and efforts by political elites to mobilize these latent memories in collective frames of ethnic superiority. Both, he claims prepared the atrocities. However, the situational dynamics of the Srebrenica massacre show that it emerged from local short-run shifts in emotions. There is no automatic, "situationfree" causality running from pre-existing motivational factors to atrocities insofar as all background conditions still need to pass through a situational turning point. (2) Standard explanations are unable to account for what massacres actually look like on the micro-level. Scholars typically treat massacres as aggregate units and thus neglect that atrocities typically unfold over several hours or days in a chain of events; we need to take these extended periods and its sequences of violence (killings, rape, mutilations) seriously. I suggest paying attention to the internal dynamics of massacres themselves, i.e. what form massacres take on the micro-level. In Srebrenica there were several different episodes of killing, some triumphant, bullying and spontaneous, some more methodical, and a halt after a few days even though more Bosnian Muslim men were being captured and without formal orders to stop the killings. Arguments based on motives, dehumanizing collective frames, or ethnic hostility, are insufficient to account for what happened locally.

${ }^{2}$ Generally, we must not confuse the rhetoric of ethnic hatred or vengeance with actual violence. 


\section{ATROCITIES AND CONFRONTATIONAL TENSION/FEAR}

Standard explanations of atrocities suffer from the intrinsic assumption that the last step, from anger, cultural prejudices, or ethnic hostility to violence is easy and automatic. However, advances in the micro-sociology of violence show that violence is not easy but difficult, especially in close-range face-to-face confrontations, and that most people shirk the performance of it even if the motivation exists and antagonists are very angry or vengeful. Most conflicts and the most typical expression of anger consist of dramatic bluster and bluff, threatening a distant enemy but not actually doing much to violently attack someone.

The key to understand violence, according to Collins, is the concept of confrontational tension/fear. He argues that violent situations are emotional confrontations, i.e. they are characterized by tension and fear. Military studies, research on police violence, and other micro-sociological studies of violence show that people feel a pervasive tension and fear in violent situations (cf. e.g. Marshall, 2000; Klinger, 2004 [1947]; Collins, 2008); micro-evidence such as pictures shows that peoples' facial expressions and postures are strained, tense, and fearful (Collins, 2008). The source of confrontational tension is not moral aversion against violent behaviour or fear of injury. It is an interactional tension/fear; it is difficult to actually hurt someone in face-to-face interaction. Thus, violent situations and what we observe in terms of violence is "shaped by an emotional field of tension and fear" (Collins, 2008: 19).

According to the micro-sociology of violence, successful, dominating violence that we observe in atrocities must overcome the interactional confrontational tension/fear, i.e. it requires special emotional conditions. According to Collins, it depends on establishing emotional dominance. Without emotional dominance, conflicts are usually standoffs, both sides making gestures at each other without much damage actually getting done. Successful violence is then a matter of one side breaking down, losing its emotional energy (EE; Collins, 2004), i.e. its confidence, internal cohesion, and lapsing into passivity, which in turn makes the other side emotionally stronger and determined. Atrocious violence comes off, then, in a reciprocal interaction: one side becomes emotionally weaker, the other emotionally stronger and violent; and this happens in a sequence of micro-interactions that feed back into each other.

War atrocities such as killing prisoners or unarmed civilians and committing mass rapes typically emerge out of violent confrontations which result in extreme shifts towards emotional dominance; they go from a period of tense standoff to a sudden overwhelming dominance of one side over passive and demoralized victims. Violence in atrocities is carried out by attacking a weak enemy, who can no longer resist; and victimhood is microsituationally constructed by being emotionally dominated, which in turn pulls in determination and violence on the other side. I want to underline the key point: pre-existing background forces per se are not enough to bring about atrocities. There must be an additional step: emotional dominance in the immediate local situation. As I will show, micro-interactions are crucial here; they constitute turning points, to or away from atrocities. What is more, the internal dynamics of an atrocity, i.e. what we observe in terms of violence, is structured by micro-situational dynamics and confrontational tension.

\section{Excursus: the concept of aggression and theories of atrocities}

A cornerstone of standard explanations of atrocities is their focus on the concept of aggression. The concept of confrontational tension/ fear challenges this constituent.

References to the concept of aggression typically take two forms in theories of atrocities:

a. The frustration-aggression hypothesis: the pathway into atrocity is conceptualized here as one that leads from experiences of frustration, humiliation, or defeat, to anger, which in turn prompts aggression (most commonly in the sense of a widespread usage of derogatory ethnic frames and epithets as well as actual violent action, cf. e.g. Horne and Kramer, 2001; Volkan, 2004).

b. Stressing the effect of social learning and/or violent (militaristic) cultural traditions on atrocities (cf. e.g. Chang, 1997).

For our purposes three aspects are important to note:

I. From a micro-interactional perspective the term aggression has several meanings:

(1) Being very energetic, proactive, rather than passive; here the word is often used in a metaphorical way: aggressive style of soccer; an aggressive advertising campaign;

(2) Being confrontational (engaging in human communicative action at cross-purposes) or seeking out a conversational confrontation;

(3) Making a violent threat (i.e. bluster);

(4) Carrying out violent action and causing bodily harm

Numbers (3) and (4) are the most relevant with regard to atrocities; the major weakness of standard explanations of atrocities is that they tend not to distinguish between (3) and (4) and do not see the difficulty of moving from (3) to (4). Verbal aggression and threats, i.e. derogatory ethnic frames and talk of ethnic cleansing, are treated as if they were the same as carrying out violent action. However, hostile language and verbal threats mostly involve bluster and bluff and do not automatically carry over into violent behaviour (Collins, 2008: 23). The micro-sociological approach shows that violence is difficult in face-to-face interaction and that we need to look at the dynamics of micro-situations for an adequate understanding of violence.

II. Cultural explanations of atrocities referring to violent, aggressive, or militarist traditions of a group do "not get closely into the process by which violence takes place" (Collins, 2008: 22). This kind of interpretation of atrocities assumes violence to be easy. There seems to be some evidence for effects of social learning; however, a micro-sociological perspective would emphasize the micro-situational aspect of it: that is, learning techniques of establishing situational dominance and thus getting around confrontational tension. Furthermore, explanations of atrocities referring to social learning assume the latter to be the necessary and often implicitly the sufficient explanation of atrocities; however, atrocities "have patterns of situational emergence in which local emotional dynamics [...] are overwhelmingly apparent" (Collins, 2008: 21). The dynamics of micro-situations are still crucial (Collins, 2008: 23). 
III. The concept of aggression tends to cut out the empirical and theoretical problem of internal dynamics of atrocities (i.e. its time-patterns and forms of violence); the broadness of the concept aggression blurs different forms and timepatterns of violent action that occur during a massacre. The micro-sociological approach to violence pays close attention to the chain of interactions (including different forms of violence) during a massacre and explicitly raises the question of what explains time-structures and violencepatterns of atrocities; as I will show below, they are patterned by micro-situational dynamics and confrontational tension/fear.

\section{A MICRO-MACRO CONTINUUM OF ATROCITIES}

Not all war atrocities are of the same kind. A theoretically useful way to classify them is along a micro-macro continuum. At the very macro-end we find atrocities that are bureaucratic, impersonal, and callous (the Holocaust would be the extreme example). Here, macro-background conditions are the key explanatory variable. At the micro-end of the continuum emotional dynamics are crucial. The micro-sociological theory spelled out in this paper focuses on the micro-end, i.e. locally caused atrocities. The arguments are developed by tracing the Srebrenica massacre through a series of phases (cf. Figure 1), based on video and other microlevel data.

\section{MATERIALS AND METHODS DATA}

I used data from the following sources:

a. Scholarly research on the Srebrenica massacre and the Bosnian civil war more generally (e.g. Honig and Both, 1997; Rohde, 1997). Of primary importance is the 2002 report by the Netherlands Institute for the Documentation of War Crimes (NIOD) of several thousand pages.

b. Indictments, statements of facts, and transcripts of the major Srebrenica trial proceedings at the International Criminal Tribunal for the former Yugoslavia (ICTY). c. Interviews that I conducted at the ICTY and with a former Bosnian Muslim interpreter for the UN in Srebrenica ${ }^{3}$.

d. More than $8 \mathrm{~h}$ of video-footage of a Serbian TV camera-team that accompanied the BSA troops. The ICTY gave me access to this video-material, which had been used during trials.

\section{DATA-ANALYSIS}

The key relevance of the micro-data was to provide insights into the situational, emotional dynamics preceding and shaping the massacre. In my analysis I have focused on dynamics of emotional dominance and its counterpart, emotional subordination. The key quality is what Collins (2004) calls emotional energy (EE), which varies between a high of confidence, enthusiasm, and emotional initiative, and a low of negative self-feelings, depression, and passivity. Emotional initiative/domination and its counterpart, emotional passivity/subordination, are produced by micro-interactions: (a) by the amount of successful solidarity rituals among group members on each side (Durkheim, 1995 [1912]), which create feelings of confidence and ebullience; and (b) by the micro-interactions between contending sides producing feelings of dominance or subordination (Kemper, 1978; Collins, 2004). In a conflict, the side which becomes dominant goes through micro-sequences of mutual attunement and emotional solidarity which gives them feelings of group strength; in addition, in its interactions with opponents, it sets the rhythm and tone of the interaction and cuts off the other side's rival attempts. In the analysis of my data-sources I have focused on each side's EE in interactions with other parties and their rituals of group solidarity. To gain an extensive picture of the atrocity's emotional dynamics, I have supplemented the analysis of EE and group solidarity with what is often considered as the primary human emotions (cf. Ekman, 2003): joy/happiness, anger, fear, sadness, and surprise.

Of particular importance for my analysis was the video-material; it allowed a close look at emotions as they unfolded over time (for the methods of video-analysis cf. Section "Video-Analysis").

${ }^{3}$ The documents under (a-b) provide in-depth descriptions of the events before, during, and after the massacre; for the attack and the atrocity itself they give detailed descriptions for each day.

(1) 1993 until summer 1995 : Standoff around Srebrenica between opposing forces of the Bosnian-Serb-Army (BSA) and the Bosnian-Muslim Army of Bosnia-and-Herzegovina $(\mathrm{ABiH})$; neither side is capable of committing large-scale violence against the other.

(2) January to June 1995, reaching a peak at 9-11 July: The UN peacekeeping force becomes demoralized by their own lack of organizational competence, and emotionally dominated by both, the Bosnian Muslims and the Serbs.

(3) 9-11 July: Collapse of the peacekeepers leads to emotional collapse of the ABiH forces.

(4) 9 July : Recognizing the sudden enemy weakness, the BSA becomes emboldened, and expands their military aims to take over the whole enclave.

(5) Evening of 11 July : The turning point to the massacre, as the UN commander and Bosnian Muslim representative show themselves paralyzed under the BSA commander's domineering manner.

(6) Afternoon 12 July to morning 13 July: The emotionally triumphant, bullying, humiliating phase of the massacre.

(7) 13 July - 16 July : Routinization of the massacre into impersonal killing methods and by 19 July gradual decline in killing. 
Furthermore, the interviews that I conducted as well as the extensive literature on the Srebrenica massacre contain rich information on the emotions on each side involved in the conflict, i.e. the BSA, $\mathrm{ABiH}$, and the UN peacekeeping forces. Based on these two sources of data I was able to create a sequential time-line, tracing the emotions on all three sides over time.

\section{Video-analysis}

The analysis of emotions in the video-material was based on methods developed by Ekman (Ekman et al., 1972; Ekman and Rosenberg, 1997; Ekman, 2001, 2003; Ekman and Friesen, 2003), Scherer (Scherer, 1982; Scherer and Ekman, 1984), Scheff (Scheff and Retzinger, 1991), and Collins (2004). My work applied their research tools on how detect emotions in micro-data. They have shown that information about emotions is identifiable in the human voice, body movements, and facial expressions; their work reveals that there are various body and facial parts that are not easily manipulated or consciously controlled; they leak information about felt emotions.

In the first step of the video-analysis I (a) transcribed the verbal communications including emphases, pauses, voice pitch, and other paralinguistic markers (cf. Section "Transcribing Conventions" in Appendix for transcribing conventions) ${ }^{4}$ and (b) described all nonverbal behaviour in close detail. To do so I conducted a moment-bymoment sequential analysis of the video-tapes; multiple viewings including in slow-motion allowed me to track nonverbal behaviour in different parts of the body and provide for a high level of accuracy and confidence in the descriptions. In the second step of the analysis I made inferences about emotions from the observed verbal and nonverbal cues; to do so I constructed a list of indicators for group solidarity, EE, and primary emotions from the works by Ekman and others (cf. Section "Emotional Cues" in Appendix). This procedure permitted the detection of emotions as they occurred in moment-by-moment sequences. In the presentation of my results below, there is room to include only a few segments of the videomaterial. I picked those that were crucial in establishing situational emotional dominance.

\section{RESULTS}

MICRO-SITUATIONAL ANTECEDENTS OF THE SREBRENICA-MASSACRE Standoff phase and the Serbian attack on Srebrenica (Phase 1)

In retrospect the 2-year period between 1993 (when Srebrenica was declared a UN safe area) and 1995, which was characterized by waves of raids, sniping, and smaller skirmishes around Srebrenica from both sides (Bosnian Muslims and Serbs) might look as if it anticipated the massacre. However, when the Bosnian Serbs began their military operations against the enclave at the beginning of July 1995, there were neither plans to take over the whole enclave, nor expectations of easy military victory, and nor plans to exterminate all Muslim men. Short-run emotions determined what happened.

When the BSA had started their attack on July 6 , the UN forces were the first to break down emotionally, setting off chain reactions among the other parties.

${ }^{4}$ The video-recordings provide transcriptions in subtitles, including official translations from Serbian into English. I have refined the transcriptions of everything that was said in English.

\section{Increasing Serbian emotional dominance over the UN forces (Phase 2)}

The level of EE among the Dutch peacekeepers was low already before the Serbian attack. They were frustrated from typical strains of peacekeeping missions (cf. NIOD, 2002; Sion, 2006): (1) Tensions with the local population they were supposed to protect; (2) Interference by contending parties with supply convoys; and (3) Relatively light weaponry (to keep up a neutral image), which made the peacekeeping forces feel weak. In theory, the UN force was supposed to be superior because of its ability to call in air strikes. In practice, however, those air strikes that were deployed were so limited and ill-timed that they served chiefly to anger the BSA without harming their local military power. Bureaucratic strains undermined more forceful air support. The UN mission suffered from an extremely complex and bureaucratic form of command, which created severe malfunctions in the flow of information between Srebrenica and higher UN authorities. The bureaucratic procedure was an effort to keep up an image of neutrality by following rules in a highly formalistic manner. In contrast, effective war-time armies try to avoid bureaucratic procedures in combat (Marshall, 2000 [1947]).

Shortly after the start of the Serbian attack, the peacekeeping forces retreated from several of their observation posts (OP). In response to the withdrawal, Bosnian Muslims threatened or attacked peacekeepers; in one incident a Dutch soldier was killed. These assaults increased the suspense among the Dutch. They became disoriented and paralyzed by being attacked from both sides. Almost all actual violence in fact is two-sided; any other structure seems difficult, because too disorienting for fighters to sustain ${ }^{5}$. Ultimately, the Dutch reached a level of fear at which they could no longer play an active role in the conflict. Peacekeepers panicked in several incidents and blocking positions, set up to deter Serbian advances into the town-center of Srebrenica, were given up quickly when shells exploded in the vicinity. The Dutch were emotionally overwhelmed and became focused on their own weakness.

\section{The situational construction of a weak victim - the Bosnian Muslims (Phase 3)}

The Muslim troops had been holding their own military positions for many months and engaged themselves in numerous raids into Bosnian-Serb territory. However, the panic among the Dutch and the surrender of OPs set off a negative spiral among the $\mathrm{ABiH}$ forces. After initial outbursts of righteous anger against the Dutch, depression and fear set in and quickly impaired all action. Over the whole course of the Serbian attack, the Bosnian Muslims put up little resistance and the defensive lines disintegrated rapidly; a large part of their ammunition remained unused (NIOD, 2002: Part III, Ch. 5/6; Rohde, 1997: 43).

\section{Growth of Serbian emotional dominance (Phase 4)}

The paralyzation among the $\mathrm{UN}$ and $\mathrm{ABiH}$ forces emboldened the BSA and pulled in their determination and initiative. When the Serbs began their military operations against Srebrenica, they had

${ }^{5}$ The multi-sidedness of pillow fights and other playful violence is the exception; these have the form of self-entertainment. Crucially, if they turn serious they tend "to fall into a two-sided pattern", most typically a "ganging up on the weakest victim, the one most prone to break down." (Collins, 2008: 13) 
not intended to take over the whole enclave but only to reduce its size. The military aims were extended only at the end of the third day of the operation (July 9), when their attack did not meet serious resistance (NIOD, 2002: Part III, Ch. 7). In fact, the Serbs ran their military operations cautiously. They tried to prevent closeproximity fights with the $\mathrm{ABiH}$, advanced only gradually, and at night often retreated into hideouts. Also, the Serbs used their artillery against the Dutch and $\mathrm{ABiH}$ mainly to intimidate them (the low number of casualties is striking here). Similarly, BSA soldiers blustered and engaged in dramatized postures of confidence (e.g. the three-fingered Serbian salute) when they tried to force the surrender of UN OPs (Rohde, 1997: 30). These are group rituals, creating an appearance of "being tough" and "mean" (Katz, 1988: 81). Grossman stresses the key role of posturing in combat; he notes that whoever "puffs himself up the biggest [...] is likely to win" and that "battle is a process of posturing until one side or another turns and runs." (Grossman, 2004: 198) The victory of the Serbs was achieved through emotional battering rather than physical destruction.

When the BSA's posturing triggered fear and passivity among the UN and Bosnian Muslim forces, this in turn led to a steady rise in the Serbs' determination, excitement, and their use of violence. In video-recordings a BSA officer charges his troops: "They are in panic. [...] Move so as to force them out. [...] C'mon push it

Mladić (M): So you ordered to shoot my soldiers and that NATO airforce you requested that NATO airforce strike at my troops?

Translator $(\mathrm{T}): . .{ }^{*}$

Karremans (K): No not again that's not decided by me ehhh ( $<1 \mathrm{~s})$ nor asked for. The time say when they are over they make decisions on what I wou on information eh from ehe the bottom eh toeh Sarajevo to eh the United Nations in New York.

T: Once again, that decision was not made by me but rather on the basis of the information that I gave you. The decision was made at a higher instance.

M: Do not fantasise Lieutenant-Colonel, Sir, but answer my question: did you order your troops to shoot at my troops?

$\mathbf{T}: . .$.

$\mathbf{K}$ : I gave the order to defend themselves (slightly breaking voice).

$\mathbf{T}: \ldots$

K: That's ... (unintelligible)

M: Who were they defending themselves from, when no one was attacking them?

$\mathbf{T}: \ldots$

$\mathbf{K}$ : I've been attacked by mortars and by tanks.

T: I was attacked.

M: In accordance with the agreement of April and May 1993, you Lt-Colonel were due to disarm the Muslims. now; they are in trouble. NATO pact can't do anything to us." This further strengthened when the BSA entered Srebrenica town on July 11 and found its centre abandoned. On video-recordings we see officers in a joyous mood; smiling faces and hugs indicate their delight. Soon, however, General Ratko Mladić, commander of the BSA troops, forcefully urges his troops to move on: "Let's go boys, move! [...] Take advantage of the panic among the Turks!" These local emotional dynamics fit the pathway into atrocity outlined at the beginning: one side acquires emotional dominance while the other side looses its organizational cohesion and becomes emotionally paralyzed and passive; a pattern of attacking a weak victim is situationally constructed, providing a pathway around confrontational tension/fear and the impetus towards atrocity.

\section{The micro-situational turning point into the massacre (Phase 5)}

After the Serbs' occupation of Srebrenica town, General Mladić and the commander of the Dutch peacekeeping forces in Srebrenica, Lieutenant-Colonel Karremans met. The emotional content of the interaction has a clear structure: Mladić forces micro-domination on Karremans. This constituted an important momentum towards the massacre; it dramatized the emotional dynamic that had crystallized before: the situational construction of a weak victim.

Right at the beginning of the meeting Mladić challenges Karremans; it is an attempt to establish situational dominance:
Mladić's (M) head and gaze are turned downwards. He then directs his gaze towards Karremans (K). M stands with his hands on his hips and elbows turned outward. K stands stiff, with arms folded before his abdomen. He looks at $M$ and scratches and strokes his right arm with the thumb of his left hand.

$K$ looks at the Translator (T) and continues to heavily scratch and stroke his right arm. Before Thas completed the translation, K looks down.

$K$ shakes his head as a 'No'; short gaze aversion; $K$ then shifts gaze to $T$; then gaze aversion; K's head and upper body then slightly bowed; he looks slightly from below to $M$ and moves right arm up to his left; $K$ next raises his left hand and then looks at the ceiling with his head turned backwards; next Klooks at $T$, then at $M$ with his chin slightly down, then wheels his head slightly.

While T translates, M stares at $K . K$ wheels his head slightly in a horizontal direction, looking into T's direction.

$K$ shortly folds his arms in front of his chest, then holds his throat and cheek with his left hand and strikes his skin; $K$ and M look at each other.

$K$ still holds and rubs his cheek/throat. Then re-folds his arms in front of his abdomen.

K: at first gaze down. At the end he looks at M; slight sway of his body.

$K$ looks down; $M$ cuts in with firm and loud voice:

$M$ and $K$ look at each other.

K looks at M; sway with torso.

At the end of the translation K looks down.

K looks at $M$; then shortly outside the window on his right; then back at $M$. 


\begin{tabular}{|c|c|}
\hline $\mathbf{T}: \ldots$ & K nods; looks shortly down; slight sway with torso. \\
\hline $\begin{array}{l}\text { M: instead, you armed them, you engaged in black-marketing with them } \\
\text { and prepared them to fight against the Serbs. }\end{array}$ & $\begin{array}{l}\text { Klooks down, then at } M \text {; wrinkled forehead; inner corners of eyebrows raised; } \\
\text { at end K looks down shortly. }\end{array}$ \\
\hline $\mathbf{T}: \ldots$ & $\begin{array}{l}\text { K looks at T. When T translates the accusation that the Dutch gave weapons } \\
\text { to the ABiH K shakes his head once as a 'No' and says very softly 'No'. At the } \\
\text { end K takes a very deep breath and looks down. }\end{array}$ \\
\hline $\begin{array}{l}\text { M: on top of that, you've ordered your troops today to shoot at my } \\
\text { soldiers. }\end{array}$ & $\begin{array}{l}\text { K folds his arms before his abdomen; he holds his wrists with his hands and } \\
\text { swallows strongly; repeated sway with torso. }\end{array}$ \\
\hline
\end{tabular}

*I am quoting the translation by the interpreter only where it deviates from Mladic's or Karremans' statements.

Mladić's persistent, direct gaze into Karremans' eyes and the repeated use of the word 'you' is an acting out or display of anger whether he feels it or not - which is expressed from a dominant position. This is an attempt to create situational dominance. Karremans' stiff body posture, body manipulators, facial expressions, as well as speech pauses and errors in contrast signal fear, unease, and potentially feelings of helplessness (Ekman, 2001). This is true also for the various forms of gaze aversion such as looking to the side or to the ceiling (cf. Scheff and Retzinger, 1991; Ekman, 2001). At the same time, the video-scene shows that Karremans is able to mobilize some resistance. He counters one of Mladićs challenges, for example, by stating that he had been attacked. However, Mladić immediately raises his voice in response, trying to break the resistance. That he is successful can be seen in Karremans' reaction: he fidgets with his arms, holds his throat, and his forehead shows strong wrinkles; these cues indicate fear and discomfort (Ekman, 2001: 111-112). Furthermore, in response to Mladićs false accusation that the Dutch had provided the ABiH with weapons, Karremans says 'No' with a very soft voice but allows Mladić to talk over him.

Karremans (K): That's eh what they (UN and Dutch governmental authorities)
have asked for.

Translator (T):...

K: eh I don't know if I may eh expect an answer.

$\mathbf{T}: \ldots$

K: Because I am realizing that ehh those ehh questions should be asked eh in Pale.

$\mathbf{T}: \ldots$

K: Or in Sarajevo. I've never been there, so I don't know how that works over there.

$\mathbf{T}: \ldots$

K: I'm eh what eh I used to say a piano player.

$\mathbf{T}: \ldots$

K: Don't shoot the piano player.

$\mathbf{T}: \ldots$

Mladić (M): You are a lousy piano player.
Generally, Mladić used staged anger and other intimidations at those points during the meeting in which his situational dominance became potentially questioned. This was the case for example when Karremans referred to his superiors. Mladić reacted forcefully to these potential threats to his situational power; in one example, he blusters in response, that there is little use for Karremans to talk to his superiors since they could not help him. These are attempts to bring in everything to the local situation and secure full emotional dominance. Ultimately, Mladić succeeded: Karremans became entrained in a negative feedback-loop in which he focused on his own intimidation/fear and uncomfortableness and the strength of the other side; he became passive and unassertive. At no point did he take a strong position. Mladić in contrast acted from a position of emotional dominance.

Karremans' lack of EE (passivity) and fear is well illustrated by the following scene in which he neglects to back his superiors' requests vis-à-vis Mladić but instead withdraws all initiative; the metaphor of the piano-player, which he uses, shows that he is caught in his own uneasiness. Mladićs reaction is a sign of emotional dominance:

$M$ and K: mutual gaze; $K$ : hands folded before his abdomen; at end K moves left arm outward.

$M$ and K: mutual gaze; towards end K looks down.

$K$ : slight shrug; K looks in-between $M$ and T with gaze straight ahead; at end he looks at $M$.

$K$ looks in-between $T$ and $M$.

$K$ moves his left hand shortly outward - slight emphasis on Pale. (He refers to negotiations at a higher (evel).

$K$ slight sway with torso.

K: raised brows, slight sway of body and head. Then shakes his head as 'No' and shrug with right shoulder. $K$ moves head between $M$ and $T$. He then swiftly moves his arms before his abdomen in and outward; at end arms and palms up.

$K$ holds his belt at his back with his left hand; then re-folds his hands before his abdomen.

Prolonged gaze to $M$ at the end, as if waiting for a reaction; no reaction from $M$.

$M$ looks at $K-K$ looks to floor.

Klooks at $M$.

$K$ looks at $M$; twice moves left hand outward in a rotating movement; then covers mouth with hand. 
Karremans' body language and statements signal intimidation/fear and passivity (low EE). The repeated fidgeting with his arms including the rotating movement with his hand at the end indicates uneasiness, i.e. low EE. Similarly, the shrug (with right shoulder) and the raising of his arms with palms up, signal impotency and passivity (cf. Ekman, 2001: 102-104). At the end Karremans covers his mouth with his hand; according to Ekman, this hiding behaviour is an indicator of emotional distress. Karremans succumbed to passivity and fear.

At 11.30 p.m. the same night, another meeting took place between Mladić and Karremans, this time also with a representative of the refugees (Nesib Mandžić - NM). Here, we see a dramatization of self-determination and confidence by Mladić. Mandžić is made to enact the position of the victim, representing

Mandžić (NM): I need to tell you General (1 s) I am telling you honestly I have been chosen as a representative by chance. But if you're not satisfied with me that's no problem.

Mladić (M): That is your problem. Bring the people who can secure the surrender of weapons and save your people from destruction.

The last scene illustrates how the interaction has taken over a coercive and disrespectful form. The micro-situational events have triggered an escalatory pathway. The meetings constituted the peak of an emotional dynamic in which the Serbs gradually established emotional dominance. They felt the passivity and fear among the Dutch and Bosnian Muslims. Conflicting sides are sensitive to the emotional state of the other side. They can feel the other side's strength but also when it is falling apart; it is the latter that gives the momentum towards violence.

\section{THE MASSACRE (PHASES 6 AND 7) Onset of deportations}

According to the ICTY and NIOD, a plan to deport and kill all men among the refugees at the UN compound in Potočari (in the north of the enclave) was made during the night of 11-12 July or in the morning of 12 July, i.e. after the meetings. They created the emotional shift into the atrocity.

The determination of the Bosnian Serbs can be seen when they moved troops, buses, and trucks into Potočari on July 12 for the evacuation of the enclave. When they arrived, they came face-to-face with UN soldiers standing guard at a cordon line, which was marked with red-and-white tape and shielded the refugees from the Serbs. Initially, Mladić and other Serbian soldiers stopped at the cordon. In conversations with peacekeepers, Mladić, however, blustered that he is in charge and everything will be done according to his orders (Rohde, 1997: 203-204). The Dutch showed strong signs of fear and low EE: their faces are distorted and strained; some shift from foot to foot and avoid gaze (cf. Ekman, 2001; Collins, 2004). Shortly after, Serbs stepped over the cordon-tape. The peacekeepers lost control over the situation; soon, Serbs urged the refugees to run to the buses. When the Dutch tried to send jeeps with the bus-convoys this became a humiliating experience; their jeeps, helmets, and those who are soon to be killed. After demanding that the $\mathrm{ABiH}$ turn over their weapons Mladić adds in an overtly slow and calm way:

\begin{tabular}{|l|l|}
\hline Mladić (M): Have I made myself clear? & Mleans forward and speaks slowly \\
(4.5 s) Nesib (1 s) the future of your & and softly. \\
people is in your hands $(1.5 \mathrm{~s})$ not only & \\
in this territory. & \\
\hline
\end{tabular}

Mladićs body posture is self-confident. With the long pauses he lets the listeners experience their uneasiness; they dramatize the power stratification. Meanwhile, Mandžić shows body-manipulators that indicate strong fear and distress; they increase in the further course of the scene:

NM looks to Mand opens his mouth and bends forward as if to say something. When someone in the room stands up, NM hesitates. He diverts his gaze and presses his lips in an 'embarrassed smile'. After a second hesitation, he closes his eyes shortly, looks away from $M$ and then abruptly turns back. He raises his hands with palms up and starts speaking $13 \mathrm{~s}$ after $M$ had finished.

NM turns his eyes shortly away and closes them. When he turns his eyes back to $M$, a prolonged shrug occurs and a crying face can be detected when looking at the video-record in slow-motion. At the end of M's remark, NM stares at the table.

flack-jackets were stolen on the way at gunpoint. What is more, as refugees walked up to the buses, Serbian soldiers separated all men from women and children; Mladić had given the order. The Dutch barely interfered. Over the course of 12 and 13 July the women and children were transported to Bosnian-Muslim held territory and the men $(\sim 1,000)$ were brought to mass-collection points outside the enclave.

\section{The emotionally triumphant, bullying, and humiliating phase of the massacre}

Killings first occurred in the afternoon of July 12 in Potočari, sometime after the arrival of Serbian troops. These killings took place amidst an emotional blending of celebrations and confident posturing and blustering among the Serbs, and fear and depressed passivity among the Dutch and refugees. The emotional dominance and mood of celebration among the Serbs was at its high point. They "swaggered and radiated confidence, casually approaching the Dutch and Muslims in small groups" (Rohde, 1997: 194). Some blustered, taunted, and cursed Muslims by shouting "Fuck your Turk mothers!" and "Where is Naser now?! [...] Look what he has done to you" (Rohde, 1997: 195) referring to the famous $\mathrm{ABiH}$ leader of Srebrenica. Some sang nationalist songs. These are Durkheimian rituals (Durkheim, 1995). Parading and breaking taboos by humiliating and deliberately scaring weak victims carry their own emotional attraction and generate feelings of confidence (cf. Katz, 1988). NIOD notes, there "was an almost hysterical elation among the troops" (NIOD, 2002: Part IV, Ch. 4).

Groups of Serbian soldiers picked up men from the crowd of refugees and executed them in the surroundings. The fact that men were typically picked up or killed by groups of Serbian soldiers shows that the killings depended on the collective mood. 
Although each Serbian soldier was armed and the victims were not, the killings needed group emotional dominance and support (cf. Grossman, 2004). It shows that when violence does occur, it unfolds "in an interactional process that is oriented in detail to overcoming the confrontational tension, while continuing to leave traces of it" (Collins, 2008: 27).

Interactions between Dutch and Serbian soldiers in Potočari constituted an escalating factor. Strong signs of fear among the Dutch emboldened the Serbs. While they initially asked peacekeepers whether they would be willing to trade flak jackets or pistols and gave up when the Dutch refused, in the afternoon, as the Dutch showed themselves paralyzed, they started to rob these items at gunpoint. The Dutch's fear dramatized the Serbs' emotional dominance; it fed back also into the killings; there is some evidence that they increased. Over the course of the day and following night 100-400 men were killed; some mutilations occurred. After the killings had gone on for some time, Serbs also began to rape women. This appears to be a general pattern of rapes in atrocities. Collins (2008) notes that rapes typically occur only after killings have been going on for some time.

The killings and abuses in Potočari were not ordered but likely encouraged by Serbian commanders (NIOD, 2002). Some had been in attendance or nearby the earlier meetings, which emboldened them and led to a mood of excitement. Emotional dynamics now fed onto each other. As the peacekeepers in Potočari proved emotionally incapable of interfering with the deportations and killings and showed heavy signs of fear, this had a strong effect on the regular troops. It established full emotional dominance and led to a "moral holiday" (Collins, 2008), i.e. a free zone without social controls ${ }^{6}$. Nevertheless, in the rare cases in which a peacekeeper complained when Serbs were picking up Muslim men, they gave in. This shows how the massacre depended on full emotional dominance.

In summary, the crucial aspects of these first killings were the situational, emotional dynamics that worked into it. Different dynamics enmeshed here:

(1) the build-up of confidence among the Serbs over the course of the attack,

(2) the emotional impetus from the meetings,

(3) in Potočari, the stark emotional contrast between the Serbs and fearful Muslims and Dutch triggered a feedback loop in which Serbian soldiers became more and more emboldened, determined, and violent.

Beyond the Srebrenica massacre itself, I want to highlight first theoretical conclusions: (a) Massacres occur by attacking a paralyzed victim. Local, emotional dominance paves the way into atrocity; it

${ }^{6}$ The killings in Potočari were not as emotionally wild as other atrocities such as the Nanking massacre (Chang, 1997). In some cases Serbs were looking for specific people or were asking for people from villages that had been the target of $\mathrm{Mu}$ slim raids during the two-year standoff. Atrocities in fact show variation along a continuum from more calculating and selective targeting towards heavy emotional carousing such as in the Nanking massacre with widespread and prolonged celebratory destruction, torture, killing games, and orgiastic rapes. However, even in atrocities in which specific targeting is involved, it is the overall atmosphere, i.e. the emotional dominance that makes the violence happen. In other words, emotional dominance is still necessary. is produced in micro-interactions. (b) Micro-interactions and their emotional outcomes determine where and when atrocities do or do not come off; they create the short-run shifts in emotions that establish the situational turning point into violence. (c) Situational emotional dynamics are crucial to understand what an atrocity looks like on the micro-level: Triumphant, carousing killings, which are often found at the onset of massacres (e.g. Chang, 1997), are triggered by the emotional shift into the atrocity. The swift rise in emotional dominance after a period of tension unleashes ebullience and violence. Here, the emotional contrast between a dominant side and a weak, paralyzed victim reinforces itself in a negative feedback loop.

\section{Towards mass-executions}

After about 12-16 h (i.e. early on July 13), the triumphant, bullying killings declined. As the evacuation resumed in the morning of July 13, less and less refugees were left in Potočari. This led to an atmosphere permeated by organizational procedures, which broke off the rituals of killing and wore down the celebratory mood. Video recordings of Serbian soldiers patrolling at the buses show mostly neutral faces. More generally this suggests that as soon as organizational procedures take precedence in atrocities, the carousing atmosphere wears off. Here we see that the internal pattern of violence in atrocities is a situated process.

The killing of the remaining Bosnian Muslim men (including several thousand men who were captured while trying to flee the enclave) turned into methodical mass executions: victims were typically shot from behind (often they were also blindfolded or had to lie with faces down). The avoidance of face-to-face confrontation reduces the emotional stress of killing (Grossman, 2004). It appears that the emotional rush is gone. Some Serbs were repulsed and arguments broke out about who would finish up wounded victims. Also, many Muslim men who were captured by Serbian soldiers after July 19, i.e. after the end of mass-executions, were not killed but brought to prisoner of war camps. These findings illustrate again that the key for the massacre to occur was the build-up phase and the emotional shift at the turning point into the atrocity. Crucially, this first dynamic lost its power over time. We see an emotional dynamic flowing in time: a build-up, turning point, peak, and falling off.

The findings on the internal structure of the massacre illustrate some of the points raised at the beginning: (a) Not only the occurrence but also the form of atrocities is a situated process; (b) Violence is difficult and even where it occurs, its dynamics and forms are still structured by a field of confrontational tension/fear. (c) In sum, confrontational tension/fear and situational microdynamics (emotional and interactional) are crucial to explain the internal patterns of violence in atrocities: (i) Carousing killings that can typically be found at the onset of massacres are unleashed by the emotional shift at the turning point into the atrocity; the swift rise in situational dominance triggers violence and exuberance (incl. rituals of humiliation and taunting). (ii) The concept of confrontational tension helps explain why killings in massacres are often committed in groups, even against a single, unarmed victim: since the main physiological characteristic of violence is confrontational tension, it needs an atmosphere of complete emotional dominance - group solidarity is a key ingredient here. 
(iii) Shouting humiliating remarks during atrocities creates selfentrainment and boosts EE and dominance (Katz, 1988); it helps overcoming confrontational tension/fear. Standard explanations of atrocities do not capture this situated process. (iv) Emotional, situational dynamics explain shifts in the form of killings during an atrocity; in our case, the shift away from triumphant and ebullient killings (including the usage of tools to reduce confrontational tension such as blindfolds) occurred as organizational procedures took precedence and the initial atmosphere wore down.

Beyond the aspects that can be addressed here, the empirical phenomenon of internal dynamics of atrocities opens up an array of additional questions that need to be addressed in future research; for example: Why do atrocities extend over varying periods of time? What explains how quick the initial atmosphere at the turning point into the atrocity peters out?

\section{CONCLUDING DISCUSSION}

The empirical analysis presented has three main theoretical implications: (1) Atrocities have a pattern of situational emergence. Emotional dynamics are crucial to explain where and when and in what manner atrocities unfold. (2) Micro-interactions and their emotional outcomes constitute situational turning points towards, or away from atrocities. The key micro-situational trigger towards atrocity is the swift disintegration of an opponent. Here, small moves one way or another can have large-scale consequences. In the Srebrenica case we saw an emotional build-up phase and a situational trigger when the peacekeeping commander showed himself paralyzed in the face of implicit threats, and the defeated Muslims themselves turned passive. It was at this moment that the local commander gave the order for the massacre. (3) Emotional dynamics are crucial to explain the internal (time)-dynamics of atrocities. For the Srebrenica massacre this paper identified an emotional flow over time with a triumphant, humiliating phase of killings at the beginning, a wearing down of the initial atmosphere after several hours, a shift towards mass executions (including measures to reduce the emotional stress of killings such as blindfolding), and an end of the massacre after several days. These findings show that forms and time-dynamics of killings during massacres are structured by a field of confrontational tension. Background factors are insufficient tools to explain what atrocities look like.

\section{APPENDIX}

\section{Appendix I| Transcribing Conventions.}

\begin{tabular}{|c|c|}
\hline \multicolumn{2}{|l|}{ 1. Pauses } \\
\hline Nesib (1 s) the future of your people & $\begin{array}{l}\text { Numerals in parentheses indicate } \\
\text { the length of a pause in seconds. }\end{array}$ \\
\hline \multicolumn{2}{|l|}{ 2. Stress } \\
\hline Let's go boys move! & $\begin{array}{l}\text { Bold prints indicate stress in } \\
\text { volume and voice pitch. }\end{array}$ \\
\hline \multicolumn{2}{|l|}{ 3. Transcriber's comments } \\
\hline $\begin{array}{l}\text { K's gaze is directed downward. His } \\
\text { hands are folded before his } \\
\text { abdomen. }\end{array}$ & $\begin{array}{l}\text { Italics contain the transcriber's } \\
\text { comments on body language, facial } \\
\text { expressions, and vocal manners. }\end{array}$ \\
\hline
\end{tabular}

\section{Appendix II | Emotional Cues.}

\begin{tabular}{|c|c|}
\hline $\begin{array}{l}\text { High-Low } \\
\text { Emotional } \\
\text { Energy (EE) }\end{array}$ & $\begin{array}{l}\text { High EE/Confidence in interactions with } \\
\text { contending side: } \\
\text { Voice: loud, firm voice - in power-position: talking over } \\
\text { other person; interruptions; challenges/dares; blaming; } \\
\text { criticism; threats; ultimatums. } \\
\text { Body Language and Facial Expressions: moving firmly; } \\
\text { taking initiative in interactions; strong physical presence } \\
\text { by making oneself large: standing erect and/or hands on } \\
\text { hips - in strong power position: cf. anger. } \\
\text { Low EE/Confidence in interactions with } \\
\text { contending side: } \\
\text { Voice: oversoft speech; irregular rhythm; fragmented } \\
\text { speech; frequent and long pauses; stammering; fill } \\
\text { words; defensiveness; repetition; self-interruption; } \\
\text { vagueness, unfinished thoughts (all indicate disorganized } \\
\text { thought processes typical of states of low confidence). } \\
\text { Body Language, Face: stiff stance; leaning away from } \\
\text { other person; avoiding gaze (head down or turned to } \\
\text { side, lowering and closing eyes); blushing; struggle for } \\
\text { control such as biting the tongue, false smiling, turning } \\
\text { the lips in, biting or licking them; hand touches or covers } \\
\text { face, eyes, mouth; hands touching hair, neck; scratching; } \\
\text { passivity; postures and movements that are shrinking, } \\
\text { hesitating/vacillating, disjointed, withdrawing; fumbling } \\
\text { (fingering of the clothing; twisting of the fingers); } \\
\text { sweating; blanching; tremor of hand. }\end{array}$ \\
\hline $\begin{array}{l}\text { Group } \\
\text { Solidarity }\end{array}$ & $\begin{array}{l}\text { High group solidarity: fine-tuned, smooth flow of } \\
\text { verbal and nonverbal behaviour; moving towards one } \\
\text { other; hugging/body contact; mutual eye contact - } \\
\text { Scheff (Scheff and Retzinger, 1991) refers to this as } \\
\text { attunement. } \\
\text { Low group solidarity: low attunement - cf. also } \\
\text { indicators of low confidence/EE. }\end{array}$ \\
\hline Anger & $\begin{array}{l}\text { Overlap with acting confidently (and from a strong } \\
\text { power-position); can be distinguished based on context } \\
\text { information. } \\
\text { Voice: talking over other person; interruptions; } \\
\text { challenges/dares; blaming; criticism; threats; } \\
\text { ultimatums. } \\
\text { Body Language, Face: Brows lowered and drawn } \\
\text { together; tensed upper and lower lid; direct hard gaze; } \\
\text { lips firmly pressed together or open \& tensed in } \\
\text { squarish shape; clenched fists; moving firmly. }\end{array}$ \\
\hline Fear & $\begin{array}{l}\text { There are strong overlaps with the low end on the EE } \\
\text { continuum. } \\
\text { Voice: cf. low confidence, esp. oversoft speech; irregular } \\
\text { rhythm; fragmented speech; stammering; fill words; } \\
\text { suppressed references; unfinished thoughts. } \\
\text { Body Language, Face: brows raised and drawn together; } \\
\text { wrinkles in centre of forehead; raise upper eyelid; raised } \\
\text { and tense lower eyelid; open mouth; drawn back tensed } \\
\text { or stretched lips; struggle for control; hand touches or } \\
\text { covers face, eyes, mouth; postures and movements that } \\
\text { are shrinking; manipulators. }\end{array}$ \\
\hline
\end{tabular}

(Continued) 


\begin{tabular}{|l|l|}
\hline Sadness & $\begin{array}{l}\text { Body Language, Face: Inner corners of eyebrows are } \\
\text { drawn up; upper eyelid corner is raised; corners of the } \\
\text { lips are down or the lip is trembling; shrinking body } \\
\text { posture; struggle for control; hand touches or covers } \\
\text { face or eyes. For sadness that corners on depression cf. } \\
\text { clues for low EE. Sadness can be distinguished from } \\
\text { fear based on context information and body movements. }\end{array}$ \\
\hline Surprise & $\begin{array}{l}\text { Face: Raised brows (curved and high); skin below the } \\
\text { brow is stretched; horizontal wrinkles across the } \\
\text { forehead; eyelids opened (no tenseness); jaw drops } \\
\text { open so that lips and teeth are parted but no tension or } \\
\text { stretching of mouth as in fear. To differentiate surprise }\end{array}$ \\
\hline
\end{tabular}

\section{REFERENCES}

Chang, I. (1997). The Rape of Nanking. New York, Penguin Books.

Collins, R. (2004). Interaction Ritual Chains. Princeton, Princeton University Press.

Collins, R. (2008). Violence: A Micro-Sociological Theory. Princeton, Princeton University Press.

Durkheim, E. (1995) [1912]. The Elementary Forms of Religious Life. New York, Free Press.

Ekman, P. (2001). Telling Lies. New York, Norton.

Ekman, P. (2003). Emotions Revealed. New York, Henry Holt.

Ekman, P., and Friesen, W. (2003). Unmasking the Face. Cambridge, MA, Malor.

Ekman, P., Friesen, W., and Ellsworth, P. (1972). Emotion in the Human Face. New York, Pergamon.

Ekman, P., and Rosenberg, E. (1997). What the Face Reveals. Basic and Applied Studies of Spontaneous Expression Using the Facial Action Coding System (FACS). Oxford, Oxford University Press.
Grossman, Lt. Col. D. (1996). On Killing: The Psychological Cost of Learning to Kill in War and Society. Boston, MA, Back Bay Books.

Grossman,Lt. Col.D. (2004). On Combat: The Psychology and Physiology of Deadly Combat in War and Peace. Belleville, PPCT Research Publications.

Honig, J., and Both, N. (1997). Srebrenica: Record of a War Crime. New York, Penguin.

Horne, J., and Kramer, A. (2001). German Atrocities 1914: A History of Denial. New Haven, Yale University Press.

Katz,J.(1988). Seductions of Crime: Moral and Sensual Attractions in Doing Evil. New York, Basic Books.

Kemper, T. D. (1978). A Social Interaction Theory of Emotions. New York, Wiley.

Klinger, D. (2004). Into the Kill Zone. A Cop's Eye View of Deadly Force. San Francisco, Jossey-Bass.

Marshall, S. L. A. (2000) [1947]. Men against Fire. Norman, University of Oklahoma Press.

\begin{tabular}{|l|l|}
\hline & $\begin{array}{l}\text { from fear I rely on context information and body } \\
\text { movements: fear tends to go hand in hand with } \\
\text { shrinking body postures, manipulators, struggle for } \\
\text { control (biting tongue, false smiling). }\end{array}$ \\
\hline Joy/Happiness & $\begin{array}{l}\text { Overlaps with cues for high group solidarity: moving } \\
\text { closer towards each other, group laughter, body contact, } \\
\text { mutual eye contact (no gaze aversion). }\end{array}$ \\
\hline
\end{tabular}

\section{ACKNOWLEDGMENTS}

I thank the International Criminal Tribunal for the former Yugoslavia (ICTY) in The Hague and Randall Collins for their generous support.

NIOD - Netherlands Institute for the Documentation of War Crimes. (2002). Srebrenica - a 'Safe' Area. Reconstruction, Background, Consequences and Analyses of the Fall of a Safe Area. Retrieved from http://213.222.3.5/srebrenica/ on 27 February 2007.

Rohde, D. (1997). Endgame: The Betrayal and Fall of Srebrenica. New York, Farrar.

Scheff, T., and Retzinger, S. (1991) Emotions and Violence. Lexington, Lexington Books.

Scherer, K. (1982). Methods of Research on Vocal Communication. In Handbook of Methods in Nonverbal Behavior Research, K. Scherer and P. Ekman, eds (Cambridge, UK, Cambridge University Press), pp. 136-198.

Scherer, K., and Ekman, P. (eds). (1984). Approaches to Emotion. Hillsdale, Erlbaum.

Sion, L. (2006) “ "Too Sweet and Innocent for War"? Dutch Peacekeepers and the Use of Violence. Armed Forces Soc. 32 , 454-474.
Volkan, V. (2004). Blind Trust: Large Groups and their Leaders in Times of Crisis and Terror. Charlottesville, Pitchstone.

Conflict of Interest Statement: The author declares that the research was conducted in the absence of any commercial or financial relationship that could be construed as a potential conflict of interest.

Received: 28 May 2009; paper pending published: 03 July 2009; accepted: 12 October 2009; published online: 03 November 2009.

Citation: Klusemann S (2009) Atrocities and confrontational tension. Front. Behav. Neurosci. 3:42. doi: 10.3389/neuro.08.042.2009

Copyright (0) 2009 Klusemann. This is an open-access article subject to an exclusive license agreement between the authors and the Frontiers Research Foundation, which permits unrestricted use, distribution, and reproduction in any medium, provided the original authors and source are credited. 